\title{
The Socio-Political Movement in the Provinces of the South-Western Region of the Russian Empire after the Suppression of the Polish Uprising of 1830-1831
}

\begin{abstract}
Anna S. Manoylenko ${ }^{1}$ \& Yuriy E. Manoylenko ${ }^{2}$
Independent Researcher. St. Petersburg, Russia

Abstract

Based on a wide range of sources including unpublished archival materials, the article examines the socio-political situation that developed in the provinces of the Southwestern Region of the Russian Empire in the first few years after the suppression of the Polish uprising of $1830-1831$. The authors analyze the features of the social movement in this region and characterize the actions of the imperial authorities in relation to it. The predominance of the Polish national trend in the social movement is noted, its origins and preconditions are traced. Special attention is paid to the forms of manifestation of opposition sentiments by the inhabitants of the region, which in the period under study were mainly in the character of open manifestations of discontent and demonstrative disrespect for the state power. This was a distinctive feature of the social movement in the region, in comparison with the rest of the territory of the Russian Empire. The authors emphasize the complexity of the situation for the central authorities, who, within the framework of the southwestern frontier, were forced to respond to extraordinary and rather large-scale anti-government "challenges" from privileged social strata (gentry and Catholic clergy) and, countering the "rebellious spirit", to carry out a complex policy of maneuvering between different groups of the population in the region. The conclusion is made about the inconsistency of the policy of the imperial authorities in the provinces of the Southwestern Region, due to a very complex combination of socio-political, religious and ethnic factors that emerged after the suppression of the Polish uprising.
\end{abstract}

\section{Keywords}

Frontier; Poles; Gentry; Catholic Clergy; Social Movement; Authorities; Empire; Nicholas I; Police Supervision; Southwest Region

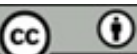

This work is licensed under a Creative Commons "Attribution" 4.0 International License

1 Email: anetkir[at]rambler.ru

2 Email: historic2009[at]mail.ru 


\section{Общественно-политическое движение в губерниях Юго-Западного края Российской империи после подавления Польского восстания 1830 - 1831 гг.}

\section{Манойленко Анна Сергеевна', Манойленко Юрий Евгеньевич²}

Независимый исследователь. Санкт-Петербург, Россия

\section{Аннотация}

В статье на основе широкого круга источников, в том числе неопубликованных архивных материалов, рассматривается социально-политическая ситуация, сложившаяся в губерниях Юго-Западного края Российской империи в первые несколько лет после подавления Польского восстания 1830 - 1831 гг. Авторами анализируются особенности общественного движения в данном регионе и характеризуются действия имперских властей по отношению к нему. Отмечается преобладание польского национального направления в общественном движении, прослеживаются его истоки и предпосылки. Особое внимание уделяется формам проявления оппозиционных настроений жителями региона, которые в исследуемый период преимущественно носили характер открытого проявления недовольства и демонстративного неуважения к государственной власти, что являлось отличительной чертой общественного движения в крае, по сравнению с остальной территорией Российской империи. Подчеркивается сложность положения центральных властей, вынужденных в рамках юго-западного фронтира отвечать на неординарные и достаточно масштабные антиправительственные «вызовы» со стороны привилегированных социальных слоев (шляхты и католического духовенства) и, противодействуя «мятежному духу», осуществлять сложную политику лавирования между различными группами населения региона. Делается вывод о противоречивости и непоследовательности политики имперских властей в губерниях Юго-Западного края, вследствие весьма сложного сочетания социально-политических, религиозных и этнических факторов, определившегося после подавления Польского восстания.

\section{Ключевые слова}

фронтир; поляки; шляхта; католическое духовенство; общественное движение; государственная власть; империя; Николай I; полицейский надзор; Юго-Западный край

Это произведение доступно по лицензии Creative Commons “Attribution” («Атрибуция») 4.0 Всемирная

1 Email: anetkir[at]rambler.ru

2 Email: historic2009[at]mail.ru 


\section{Введение}

Территория Юго-Западного края, вошедшего в состав Российской империи в результате разделов Речи Посполитой последней трети XVIII в., изначально представляла собой регион, в котором тесно переплелись национальные, социальные и политические противоречия. Включение края в состав мощной имперской системы определило его положение как фронтира, в котором представители польской нации ощущали себя угнетенным народом, оторванным от своих культурно-исторических истоков. На протяжении столетий занимая доминирующее положение в сфере государственной власти и управления, поляки, вследствие масштабных геополитических изменений, оказались в статусе национального меньшинства.

Утратив собственное государство, они особенно остро переживали ставшее «второстепенным» положение католической религии и польского языка, являвшихся основой их самоидентификации. Как следствие, основной целью патриотически настроенных польских кругов становится возрождение национальной государственности. Идеи восстановления единой и независимой Речи Посполитой оказались той питательной средой, которая на долгие годы определила основное направление общественно-политического движения в рассматриваемом регионе.

Ситуация особенно обострилась после подавления Польского восстания 1830 - 1831 гг. Столкнувшись с открытыми проявлениями оппозиционных настроений со стороны значительной части шляхты и католического духовенства, центральная власть оказалась перед необходимостью поиска более эффективных механизмов управления, нежели относительно «мягкие» практики периода царствования Александра I.

Сложность положения усугублялась разворачивавшимся на территории Подольской губернии Юго-Западного края в 1830 - 1835 гг. масштабным крестьянским движением под руководством У. Я. Кармалюка. В поисках социальной опоры в регионе правящие круги были вынуждены лавировать между «мятежной» по духу, но близкой по статусу католической шляхтой («естественной» союзницей в противостоянии с восставшими крестьянами) и крестьянством, исповедовавшим православие, но по своим социальным «чаяниям» вступавшим в конфликт с представителями государственной власти и высших сословий.

Цель данной статьи заключается в том, чтобы охарактеризовать особенности общественно-политической ситуации, сложившейся в губерниях ЮгоЗападного края в первые годы после подавления Польского восстания 1830 - 1831 гг., и проследить различные аспекты сосуществования и взаимного влияния власти и общественного движения. Основной источниковой базой для этого станут документы высших и центральных учреждений Российской империи, хранящиеся в Российском государственном историческом архиве. 


\section{Общественно-политическая ситуация в губерниях Юго-} Западного края после подавления Польского восстания

Восстание 1830 - 1831 гг. породило среди польской части населения Юго-Западного края определенные надежды на возрождение Польши. Эти настроения нашли свое отражение как в моральной поддержке повстанцев, так и в прямом участии в разворачивавшихся событиях. Наибольшую активность проявили представители польской шляхты и католического духовенства Волынской губернии, поддержавшие действия регулярного польского корпуса генерала Ю. Дверницкого, вторгшегося на территорию Волыни в апреле 1831 г. (Долбилов, 2006, с. 99).

Проявленное значительной частью населения Юго-Западного края сочувствие Польскому восстанию вызвало со стороны властей настороженность и подозрения в неблагонадежности. Отсутствие прочной опоры в социальных слоях, которые на основной территории Российской империи относились к высшим сословиям и служили надежными «столпами» государственного организма, породило у представителей администрации ощущение зыбкости установившегося порядка и желание предотвратить подобные ситуации в будущем.

Восстание достаточно остро обозначило проблему дальнейшей интеграции региона: необходимо было выработать особую стратегию в этом отношении, поскольку прежние, достаточно мягкие, управленческие практики продемонстрировали свою неэффективность. Это стало основной причиной выделения территории края в отдельную административную единицу под управлением генерал-губернатора, имевшего чрезвычайные полномочия и напрямую подчинявшегося императору ${ }^{1}$.

В 1832 г. главный начальник Третьего отделения Собственной е.и.в. канцелярии А.Х. Бенкендорф в ежегодном «Обозрении расположения умов», представленном императору Николаю I, утверждал, что Польское восстание разбудило в жителях Западных губерний «издревле питаемую к России ненависть», и признавал, что его военное подавление не способно уничтожить это чувство в сердцах местного населения (Сидорова \& Щербакова, 2006, с. 88).

При этом А.Х. Бенкендорф подчеркивал, что враждебные настроения характерны лишь для дворянства и католического духовенства, в то время как «простой народ не питает, конечно, сих чувств» (2006, с. 88). В данном суждении нашло свое отражение распространенное в правящих кругах представление о крестьянстве Юго-Западного края, как об опоре имперской власти. Оно обусловливалось известным разочарованием в региональной элите, продемонстрировавшей свой «мятежный дух», а также принадлежно-

1 О значении, которое придавалось властями Юго-Западному краю, свидетельствует тот факт, что в 1832 г., еще до введения общих губернских штатов на всей территории Российской империи, «по особым уважениям и настоятельной необходимости», были утверждены штаты для Канцелярии киевского военного, волынского и подольского генерал-губернатора. См.: (РГИА. Ф. 711. Оп. 1. Д. 6, л. 3). 
стью большинства местного крестьянства к государственной религии Российской империи - православию ${ }^{1}$.

Аналогичные оценки общественных настроений населения Юго-Западного края давались главой тайной полиции и в последующие годы. Только в 1835 г. А.Х. Бенкендорф отмечал: «Умы их постепенно успокаиваются, и в этом отношении в нынешнем году есть улучшения» (Сидорова \& Щербакова, 2006, с. 131). Однако уже в отчете за 1837 г. вновь содержались сведения о том, что «расположение их к правительству если не совершенно враждебно, то по крайности сомнительно», что вызывает необходимость «самого бдительного надзора» $(2006$, с. 162$)$.

Таким образом, в отчетах Третьего отделения отмечалась перманентная скрытая враждебность населения Юго-Западного края по отношению к имперским властям при отсутствии открытых массовых проявлений политического неповиновения. Эти оценки во многом подкреплялись мнением лиц, имевших возможность непосредственно наблюдать ситуацию в регионе. Так, один из офицеров 4-й легкой кавалерийской дивизии, следовавшей в мае 1836 г. через Волынскую губернию, отмечал, что отношение местных жителей к России «доказывает, что восстание в Царстве Польском усмирено только силою оружия» (ГАРФ. Ф. 109. Оп. 2а. Д. 283, л. 1). Подкрепляя это утверждение примерами, офицер подчеркивал «решительную ненависть и явное презрение», проявляемые жителями губернии «ко всему, что только носит имя или мундир русский» (Д. 283, л. 3).

Подобную же резкую оценку общественно-политической ситуации в крае давал назначенный в 1832 г. на должность директора Луцкой гимназии И.Г. Кулжинский: «Этот русский край тогда был до того ополячен, что все русские чиновники, служившие там, говорили и писали по-польски» (Кулжинский, 1865, с. 1). Мемуаристу удалось отметить существенную черту, влиявшую на обстановку в регионе: некоторая часть российских чиновников, присылавшихся в край для претворения в жизнь общеимперской политики, могла подвергаться влиянию господствующих в крае оппозиционных настроений, что значительно снижало эффективность их деятельности в качестве опоры центральной власти.

В то же время самими польскими патриотами из числа жителей Юго-Западного края отмечалась общая апатия, охватившая население после подавления восстания 1830 - 1831 гг. Так, дворянин Волынской губернии К. Мошковский, сражавшийся в отряде генерала Ю. Дверницкого, писал о «всеобщем омертвении», не вызывавшем даже мысли о возможности

1 Разворачивавшееся в этот период в регионе масштабное крестьянское движение под руководством У. Я. Кармалюка было «вынесено за скобки» в донесениях руководителя Третьего отделения, однако на практике оно, несомненно, оказывало влияние на отношение местных властей к шляхте и ее оппозиционной активности, в значительной степени обусловливая непоследовательность административнополицейских мер, предпринимаемых в отношении «социально близкого» правящим кругам слоя польских дворян. 
что-либо предпринять (Мошковский, 1909, с. 485). Подобную оценку общественной ситуации в крае разделял и ксендз С. Шульц, считавший, что «безумие охватило общество, безучастность к религии и Отечеству начала в нем распространяться мгновенно» (Szulc, 1868, s. 69).

Общую гнетущую обстановку отмечал и житель Киевской губернии T. Бобровский (Bobrowski, 1900, s. 30). Он видел ее причины в инициированном властями расследовании дел участников восстания, проведении конфискаций имущества и официальном запрете на общение с родственниками, эмигрировавшими за границу.

Громким событием на этом фоне стал побег за границу «государственного преступника» Н. Олизара весной 1833 г. Помещик Луцкого уезда Волынской губернии граф Н. Олизар, принимавший активное участие в Польском восстании, был задержан на территории Царства Польского и прислан под караулом в Житомир. Генерал-губернатор края В.В. Левашов распорядился передать арестованного Военно-следственной комиссии «для суждения по полевому Уголовному положению» (РГИА. Ф. 1151. Оп. 3. 1843 г. Д. 132, л. 2 об.). В ожидании суда Н. Олизар был помещен в Житомирский бернардинский монастырь под наблюдение полицмейстера К. И. Штамма.

В ночь со 2 на 3 апреля 1833 г. Н. Олизар бежал из монастыря (Д. 132, л. 3). В ходе проведенного, по высочайшему повелению, расследования было установлено, что побег организовал канцелярист Волынской уголовной палаты А. Бочковский, вывезший Н. Олизара в имение помещика К. Конаржевского в Луцком уезде, а затем скрывшийся вместе с графом на территории Австрии (Д. 132, лл. 3 об. -4 об.).

Следствие установило, что семья А. Бочковского принадлежала к числу польских патриотов и принимала «сильное участие в положении политических преступников» (Д. 132, л. 9). Отец и мать канцеляриста передавали арестованным участникам Польского восстания продукты питания, а сестра неоднократно ходатайствовала перед властями «об облегчении участи сих арестантов» (Д. 132, л. 9).

По приговору Волынской уголовной палаты, утвержденному губернскими властями и Правительствующим Сенатом, А. Бочковский был лишен дворянства и, «по поимке», должен был быть сослан на каторжные работы в Сибирь (Д. 132, лл. 8-11, 14). Однако задержать канцеляриста и бежавшего при его помощи Н. Олизара не удалось.

\section{Взаимодействие населения Юго-Западных губерний с польскими эмиссарами}

Достаточно распространенным явлением среди населения Юго-Западного края после подавления Польского восстания стала добровольная эмиграция. Основным центром польской политической эмиграции была 
Франция. На территории этой страны польскими патриотами был создан ряд организаций, ставивших целью возрождение национальной государственности и «собирание» утраченных земель Речи Посполитой. Основными способами действий были избраны пропаганда среди населения бывших польских территорий, создание конспиративных организаций, налаживание контактов с революционно настроенными кругами.

В 1833 - 1834 гг. на территории Юго-Западного края начинается деятельность польских эмиссаров. Они опирались на оппозиционные, антироссийские настроения, сохранявшиеся в среде местной шляхты и католического духовенства, как социальных слоев, воплощавших в себе основы польской национальной самоидентификации: религию, язык и культуру. Во всеподданнейшем докладе министра внутренних дел Д.Н. Блудова по этому поводу отмечалось:

«Некоторые из находящихся во Франции польских выходцев избрали из среды себя и отправили в пределы России нескольких эмиссаров с поручением произвести новые беспокойства и со злодейскими замыслами против Священной Вашей особы» (РГИА. Ф. 711. Оп. 1. Д. 7, лл. 18-18 об.).

Получив сведения о существовании польских тайных обществ в Галиции, император Николай I в качестве превентивной меры против установления контактов между ними и населением Юго-Западного края распорядился «затруднить и вовсе остановить увольнение за границу в австрийские владения дворян-помещиков и всех тамошних уроженцев» (РГИА. Ф. 1151. Оп. 3. 1843 г. Д. 132, л. 19).

Несмотря на это, жители региона достаточно активно взаимодействовали с прибывавшими из-за границы лицами. Так, например, в 1835 г. дворяне Волынской губернии И. Вольский и И. Ивашкевич были подвергнуты строгому полицейскому надзору за оказание помощи возвратившемуся из Франции по подложному паспорту политическому эмигранту Л. Вольскому (РГИА. Ф. 1286. Оп. 6. Д. 288, лл. 277 об.-280, 289 об.-290). Это обстоятельство, однако, не помешало им позднее принять в своем доме прибывших из-за границы француженок, мать и дочь Лоран, заподозренных властями в связях с польскими эмигрантскими кругами (Д. 288, лл. 298 об.-299). В то же время в укрывательстве прибывших из-за рубежа политических изгнанников был обвинен и ряд других помещиков Волынской губернии: Е. Дунина, И. Лукашевич, И. Злотовский (Д. 288, лл. 266-331, 362-365, 390-450).

Многие жители края поддерживали отношения с лицами, официально объявленными «политическими преступниками», находившимися за границей или отправленными в ссылку. Так, в 1834 - 1835 гг. полицейскому надзору были подвергнуты купцы И. Бендзинский, А. Гальперин и Я. Мейер, имевшие постоянные зарубежные контакты с польской политической эмиграцией (РГИА. Ф. 1286. Оп. 6. Д. 288, лл. 272 об., 281 об., 304 об.). В 1834 г. в связях с политическими преступниками был обвинен житель Волынской губернии М. Хонский, 
у которого при обыске обнаружили «неблагонамеренную переписку с находящимися за границей сыновьями» (Д. 288, л. 324 об.).

Отдельно следует выделить группу лиц, которые поддерживали контакты с политическими изгнанниками, не будучи связанными с ними родственными узами или родом занятий. Этих жителей Юго-Западного края можно считать наиболее убежденными идейными противниками российских властей, поскольку для поддержки польских патриотов у них не имелось самоочевидных причин личного характера.

К таковым, по данным «Ведомости о лицах, состоящих под надзором полиции» за 1837 г., относились, в частности, помещики Волынской губернии И. Злотовский, Ф. Домбровский, И. Келкевич, Б. Мияковский, Р. Ольшевская, А. Орлицкий, М. Пиотровский, И. Сохацкий, К. Ковальская, а также ксендз А. Татура (РГИА. Ф. 1286. Оп. 6. Д. 288, лл. 267 об.-331). Последний, в отличие от подавляющего большинства «неблагонадежных» лиц, был, по личному распоряжению императора Николая I, помещен под арест (Д. 288, л. 322 об.). В этом случае отягчающим обстоятельством послужило то, что ксендз А. Татура являлся участником Польского восстания, после подавления которого за ним был установлен полицейский надзор. Перепиской с «неблагонадежными» лицами он продемонстрировал властям неизменность своей «антигосударственной» позиции. Сыграл свою роль и фактор особенно настороженного отношения властей к католическому духовенству, считавшемуся одним из основных противников имперской власти в регионе.

В связях с «политическими преступниками» был уличен и ксендз М. Пулаский, служивший викарием в одном из костелов Киевской губернии. За ним, по предписанию гражданского губернатора Ф. Л. Переверзева, был учрежден полицейский надзор (РГИА. Ф. 1286. Оп. 6. Д. 288, л. 397 об.).

В октябре 1838 г. в «противозаконных сношениях с лицами, изобличенными в злоумышлении против правительства», были замечены помещицы Подольской губернии Ж. Залесская и Ф. Ивановская (РГИА. Ф. 1286. Оп. 7. Д. 3, лл. 163 об.-164., 192 об.-193). В отношении первой из них последовало личное распоряжение императора Николая I о ссылке под надзор полиции в Саратовскую губернию; вторая, по распоряжению министра внутренних дел Д.Н. Блудова, была отправлена в Курскую губернию (Д. 3, лл. 163 об.-164., 192 об.-193).

\section{Антиправительственная активность населения Юго-Западного края и противодействие ей со стороны властей}

Одной из наиболее частых форм проявления оппозиционных настроений среди жителей Юго-Западного края являлось распространение различных 
слухов антиправительственного характера. Так, например, в 1834 г. помещик Киевской губернии В. Михайловский был замечен в распространении

«нелепых слухов на счет присоединения поляков к шайке, предводительствуемой мятежником Дверницким» (РГИА. Ф. 1286. Оп. 7. Д. 3, л. 430 об.).

В 1835 г. священник из Киевской губернии И. Боровский был уличен «в рассеивании между народом разных нелепостей» (РГИА. Ф. 1286. Оп. 6. Д. 288, л. 270 об.). По аналогичным причинам, был изобличен в политической неблагонадежности ксендз И. Варховский, который, однако, несмотря на это, продолжал служить законоучителем римско-католического вероисповедания в Луцкой гимназии (Д. 288, л. 274 об.).

В 1836 г. пятеро дворян Волынской губернии попытались использовать для патриотической пропаганды проходившие в Житомире похороны австрийской подданной А. Квятковской, известной своим «участием в политических обстоятельствах» и связями с участниками Польского восстания (РГИА. Ф. 1286. Оп. 6. Д. 269, лл. 62 об.-63). «Похвальные речи» в адрес умершей были произнесены как во время церковной панихиды, так и в ходе шествия процессии по улицам города и непосредственно во время траурной церемонии на кладбище.

Властями было обращено серьезное внимание на этот эпизод. Об этом свидетельствует тот факт, что ораторы были высланы под строгий надзор полиции в Пермскую и Вятскую губернии, а не оставлены, как большинство признанных «неблагонадежными» лиц, в одной из губерний края и не сосланы в центральные великороссийские губернии (РГИА. Ф. 1286. Оп. 6. Д. 269, лл. 62 об.-63, 76 об.-77).

О происшествии было упомянуто во всеподданнейшем докладе министра внутренних дел Д.Н. Блудова, после чего последовало высочайшее распоряжение «воспретить сказывание таких речей светскими людьми не только в церквах, но и вообще в местах публичных» (РГИА. Ф. 711. Оп. 1. Д. 10, л. 40 об.). Контроль за исполнением этого предписания был возложен как на полицейские, так и на духовные власти: представителям высшего католического духовенства в регионе, под страхом наказания, было предписано строго следить за его соблюдением.

Основные формы проявления общественного движения в Юго-Западном крае, как правило, не имели четких структурных очертаний и проходили в виде нерегулярных собраний в домах тех или иных лиц. Участники собраний не шли дальше обсуждения ситуации в крае и высказывания недовольства политикой властей, направленной на установление имперского порядка. Представители администрации, тем не менее, видели в подобных явлениях определенную угрозу, поскольку предполагали, что она может стать отправной точкой для практических «мятежных» действий. 
В сентябре 1837 г. властями края было инициировано дело «О возобновлении будто бы заговора к мятежу в Волынской губернии». Расследование было начато по факту показаний одного из содержавшихся под стражей в Житомире заключенных о том, что в губернии

«...возобновляется заговор к мятежу, в котором действуют большей частью изгнанники, перешедшие из-за границы под разными именами и нашедшие убежище у соумышленников» (РГИА. Ф. 1284. Оп. 22. І отд. І ст. Д. 144, л. 10).

Получив эти сведения, генерал-губернатор А.Д. Гурьев поручил волынскому вице-губернатору В.С. Смирнову осуществить их проверку «самым осторожным и благоразумным способом» (Д. 144, л. 5 об.). Последний, в свою очередь, дал предписание кременецкому полицмейстеру И.А. Грушецкому провести расследование (Д. 144, л. 5 об.).

Через три недели И.А. Грушецкий представил вице-губернатору рапорт о том, что при римско-католическом монастыре в селении Додеркалы Волынской губернии помещиком К.В. Бобром организовывались «незаконные собрания», в которых участвовало свыше 20 местных дворян, являвшихся выразителями польских патриотических настроений и мечтавших о возрождении независимой Польши. Многие из них (Л. Ожаровский, М. Тарновский, Г. Малаховский, А. Чарноцкий, М. Новоселицкий, Я. Пичман и др.) были непосредственными участниками восстания 1830 - 1831 гг. (РГИА. Ф. 1284. Оп. 22. І отд. І ст. Д. 144, лл. 9 об.-15 об.).

Помимо не имевших определенных занятий помещиков, в собраниях участвовали три адвоката, пятеро судебных служащих, уездный лекарь, а также несколько бывших учителей Кременецкого лицея, который был закрыт властями как один из «очагов распространения преступных политических идей» (Д. 144, л. 5 об.).

Интересно, что к числу предполагаемых участников собраний был отнесен служащий заседателем в Кременецком земском суде украинец А.Ф. Овсеенко, который, по утверждению полицмейстера, «ополячился совсем» (т.е. проникся «мятежным» польским духом в результате длительного общения с представителями шляхты), а также другой заседатель, П.И. Сонцев, женатый на воспитаннице польской семьи Борковских, являвшихся «соучастниками всех прочих вольнодумцев» (РГИА. Ф. 1284. Оп. 22. I отд. І ст. Д. 144, лл. 11 об., 14 об.).

Ознакомившись с рапортом И.А. Грушецкого, вице-губернатор В.С. Смирнов отдал распоряжение чиновнику для особых поручений М.А. Пархоменко тщательным образом проверить собранные полицмейстером сведения и «дойти непременно, в чем заключается действительная цель таковых сборищ» (Д. 144, лл. 21 об.-22). В инструкции чиновнику предписывалось исключить «малейшие сомнения о действительности злоумышленных предприятий» (Д. 144, лл. 21 об.-22). 
Действуя в русле указаний вице-губернатора, М.А. Пархоменко потребовал у полицмейстера И.А. Грушецкого подробных объяснений, откуда ему стало известно о фактах собраний и неблагонадежности названных в рапорте лиц. Однако полицмейстер отказался раскрыть источники информации и не сообщил чиновнику «ничего основательного» (Д. 144, л. 16 об.). После этого М.А. Пархоменко поручил своему помощнику И.Ф. Камреру отправиться в Додеркалы и лично проверить сведения о собраниях польских патриотов.

Прибыв в селение, И.Ф. Камрер побеседовал с православным священником, который сообщил, что многие указанные в рапорте полицмейстера лица действительно собираются у помещика К.В. Бобра при католическом монастыре, однако ведут между собой лишь «обыкновенные разговоры» (Д. 144, л. 30 об.).

На основании одного этого свидетельства И.Ф. Камрер сделал вывод о «несостоятельности сведений» И.А. Грушецкого и отсутствии истинных поводов для беспокойства. При этом ни у него, ни у М.А. Пархоменко не возникло сомнений относительно того, откуда у православного священнослужителя могли быть достоверные сведения об истинных целях и содержании собраний при римско-католическом монастыре.

Затем И.Ф. Камрер тайно обратился к кременецкому земскому исправнику В.Я. Немченко с вопросом о благонадежности названных в рапорте лиц. Исправник сообщил, что,

«хотя некоторые из них неизвестны ему лично, но по наружности их ничего подозрительного не замечено, кроме польского патриотизма» (РГИА. Ф. 1284. Оп. 22. І отд. І ст. Д. 144, л. 32).

Интересно, что провинциальный полицейский чиновник не видел в «польском патриотизме» местных жителей существенной опасности для властей, полагая его вполне естественным чувством, которое имперская власть не в состоянии искоренить.

В итоге М.А. Пархоменко представил волынскому вице- губернатору рапорт о том, что сведения, представленные полицмейстером И.А. Грушецким, «заключают в себе, кроме несообразности, легковерность доносителя и даже злость и беспокойство характера его» (РГИА. Ф. 1284. Оп. 22. І отд. І ст. Д. 144, л. 35 об.). По мнению чиновника, подозрения полицмейстера относительно неблагонадежности и «злоумышлений» участников собраний в Додеркалах были безосновательны.

25 декабря 1837 г. вице-губернатор В.С. Смирнов сообщил министру внутренних дел Д.Н. Блудову, что при расследовании дела «ничего похожего на истину не открылось» (РГИА. Ф. 1284. Оп. 22. І отд. І ст. Д. 144, л. 25).

Таким образом, руководствуясь собственными служебными интересами, власти Волынской губернии намеренно не придали значения факту политических тайных собраний польских патриотов и не предприняли никаких мер в отношении их участников. Недальновидность подобного поведения обнару- 
жилась через полгода, когда в крае было начато расследование дела тайной организации «Союз польского народа», к которому оказались причастны 10 человек из числа указанных И.А. Грушецким в качестве «неблагонадежных» (Манойленко, 2015).

Основным способом наказания участников антиправительственной деятельности на территории Юго-Западного края было предание полицейскому надзору. Последний выражался в назначении для поднадзорного определенного места жительства, ограничении возможности выезда за его пределы, а также в поручении местным полицейским чиновникам осуществлять наблюдение за его действиями (Манойленко, 2013).

Со стороны властей также неоднократно декларировалось намерение привлекать «политически неблагонадежных» лиц к различным видам государственной службы. Между тем, представляется небезынтересным проанализировать то, чем в действительности занимались лица, находившиеся под надзором полиции.

В 1837 г. в Волынской губернии под полицейским надзором состоял 201 человек, в том числе 115 - по обстоятельствам, связанным с Польским восстанием 1830 - 1831 гг. (от прямого участия в мятеже до выражения сочувствия повстанцам) (РГИА. Ф. 1286. Оп. 6. Д. 288, лл. 267 об.-331). Остальные были преданы надзору по иным причинам проявления политической неблагонадежности.

Как показывает анализ источников, лишь 13 человек из вышеперечисленных занимались чем-либо, кроме ведения собственного хозяйства. При этом пятеро были управляющими в поместьях крупных землевладельцев, трое преподавали, двое являлись вольнопрактикующими лекарями, двое занимались торговлей, а один служил священником (РГИА. Ф. 1286. Оп. 6. Д. 288, лл. 267 об.-331).

Преподаванием занимался, в частности, упоминавшийся выше ксендз И. Варховский, служивший в Луцкой гимназии; двое других учителей, находившихся под надзором, занимались частной практикой. При этом один из них подозревался в связях с «неблагонамеренными людьми» за границей, а другой был в этом официально изобличен (РГИА. Ф. 1286. Оп. 6. Д. 288, л. 275). Эти факты служат примером того, что лица, по серьезным политическим причинам состоявшие под полицейским надзором, допускались к воспитанию юных подданных Империи и имели возможность влиять на их умонастроения.

Подавляющее же большинство поднадзорных, как уже отмечалось, свободно занималось ведением хозяйства. При этом многие из них, по данным полиции, продолжали свою оппозиционную деятельность. В расчет не принималось даже то обстоятельство, что 15 человек состояли под наблюдением по конкретным доказанным обвинениям, а не просто по подозрению в совершении противозаконных деяний (РГИА. Ф. 1286. Оп. 6. Д. 288, лл. 267 об.-331). Даже помещик Ф. Прушинский, помещенный под надзор полиции вследствие 
сообщений о тайных политических собраниях в его доме, не был подвергнут дополнительным ограничительным мерам и фактически пользовался полной свободой действий (Д. 288, л. 309 об.).

В Киевской губернии доля находившихся под надзором по обстоятельствам, связанным с Польским восстанием, была выше, чем в Волынской. Из 198 человек, состоявших под надзором в 1837 г., лишь 18 были преданы наблюдению по иным причинам (Д. 288, лл. 391 об.-449).

При этом положение поднадзорных в Киевской губернии было аналогичным. На государственной службе состоял лишь А. Опацкий, служивший писарем в уездном суде (Д. 288, л. 434); остальные занимались собственным хозяйством. В числе последних были четыре брата Росцишевских, состоявшие под надзором с января 1833 г. «за найденное у них оружие», а также изобличенный в том же преступлении помещик С. Осташевский, помещенный под надзор в сентябре 1836 г. (Д. 288, лл. 433 об.-438). Ксендз М. Пулаский, преданный надзору «за сношение со злоумышленниками», свободно продолжал службу в католической церкви (Д. 288, лл. 397 об.-398).

В Подольской губернии общее число лиц, состоявших под надзором полиции, было существенно ниже: в 1837 г. их было всего 10 человек, при этом лишь двое были преданы наблюдению по политическим мотивам; остальные за «дурное поведение» (Д. 288, лл. 361-365). На службе не состоял ни один из поднадзорных.

В первой половине 1830-х гг. в Юго-Западном крае начинают обнаруживаться случаи хранения и распространения запрещенной польской патриотической литературы, наполненной идеями возрождения утраченной Речи Посполитой.

В июне 1834 г. архиепископ Подольский Кирилл сообщил обер-прокурору Св. Синода С.Д. Нечаеву о появлении в крае списков «Акта открытия Польского комитета в Париже» (РГИА. Ф. 797. Оп. 4. Д. 14086, л. 1). В их распространении активное участие принимал униатский священник М. Левинский, служивший в костеле уездного города Меджибожа Подольской губернии. В личных беседах он пытался побуждать местных дворян к мятежу, знакомя их с содержанием «Акта». Один из собственноручно переписанных экземпляров «Акта» М. Левинский оставил в доме местной помещицы Л. Крымской, откуда он был доставлен к архиепископу Подольскому. Как отмечалось в донесении последнего обер-прокурору, «подобного рода сочинений, как в прозе, так и в стихах находится немало в крае» (Д. 14086, л. 1 об.).

«Акт открытия Польского комитета в Париже» провозглашал единение польского и французского народов «в любви к свободе» и «борьбе с тиранией» (Д. 14086, л. 2). Авторы документа утверждали, что оба народа «общих имеют врагов, и счастье или беды одного суть счастье или бедствие другого народа» (Д. 14086, л. 2). Документ содержал исторический экскурс взаимодействия поляков и французов в «освободительной борьбе», начиная с событий Великой 
Французской революции и восстания под руководством Т. Костюшко и заканчивая тронной речью короля Луи-Филиппа I, в которой было выказано уважение к «народному быту Польши» (Д. 14086, лл. 2-4 об.).

Основываясь на убеждении о тесном сотрудничестве двух народов в деле «борьбы за свободу», составители «Акта» приходили к выводу о необходимости основать в Париже «постоянный народный комитет» и формулировали главный лозунг его деятельности: «Польша! Польша Ягеллонов, неподвластная, свободная или наша смерть!» (Д. 14086, лл. 4 об., 6 об.).

Документ содержал не только общие пожелания увидеть польские земли независимыми, но и прямые призывы к планомерной вооруженной борьбе с целью выхода из состава Российской империи и возрождения собственного государства.

Распространение «Акта» среди дворянства Юго-Западного края при активном участии представителя униатского духовенства, с точки зрения властей, свидетельствовало о наличии серьезного очага общественного движения, который со временем мог перерасти в реальную вспышку освободительной борьбы. Как отмечалось в упоминавшемся донесении архиепископа Подольского,

«нерасположенность многих к Всероссийскому Престолу и готовность воспользоваться каждым могущим встретиться случаем к восстанию прикрыты только и не подлежат сомнению» (РГИА. Ф. 797. Оп. 4. Д. 14086, л. 6 об.).

Архиепископ Кирилл сообщал, что обнаружение крамольного документа не было единичным, случайным проявлением оппозиционности униатского священника. По словам иерарха,

«теперь собирается в костеле и к ксендзам гораздо больше против прежнего помещиков, что подает повод к подозрению, не имеют ли они при том какого совещания» (Д. 14086, л. 6 об.).

Сведения о распространении среди жителей Юго-Западного края «Акта» Польского комитета в Париже были доложены обер-прокурором С.Д. Нечаевым императору Николаю I (Д. 14086, л. 7). Последний отметил, что, хотя сам «акт польских мятежников» властям известен уже давно, «прочие обстоятельства довольно важны» (Д. 14086, л. 7).

Хранение и распространение запрещенной литературы коснулось и других социальных слоев населения Юго-Западного края.

В 1834 г. адвокат С. Игнатович и чиновник А. Косацкий, проживавшие в Волынской губернии, были подвергнуты полицейскому надзору за обнаруженные у них «пасквильные и вольнодумные сочинения» польского патриотического характера (РГИА. Ф. 1286. Оп. 6. Д. 288, л. 289 об.).

В 1836 г. в распространении «противозаконных сочинений» были изобличены студенты университета Св. Владимира. 
«Казеннокоштный» студент Ю. Буяльский, находясь на каникулах в Волынской губернии, получил от управляющего имениями графов Браницких несколько стихотворений революционного содержания, принадлежащих перу польского поэта С. Гощинского. Вернувшись в Киев, Ю. Буяльский познакомил с одним из стихотворений («Пир мщения») студента С. Стройновского, который переписал его и, в свою очередь, передал студенту С. Рутковскому. От последнего рукопись попала к «своекоштному» студенту П. Богдановичу, который спрятал ее во дворе одного из городских домов, где она и была обнаружена властями (РГИА. Ф. 733. Оп. 69. Д. 335, лл. 70-75).

Двое других студентов, «казеннокоштный» Р. Станиславский и «своекоштный» П. Кунашевский, хранили у себя и пытались распространять среди товарищей рукопись запрещенной цензурой третьей части драматической поэмы польского поэта А. Мицкевича «Дзяды» (РГИА. Ф. 733. Оп. 69. Д. 335, л. 72 об.).

В непосредственной близости от места проживания вышеназванных студентов были обнаружены и другие рукописи «противозаконного характера», в частности, биография польского писателя И. Ходзько, «распространявшего возмутительные идеи», а также сочинение одного из депутатов бывшего Польского сейма «О товариществе взаимного вспомоществования», содержавшее

«довольно красноречиво и систематически изложенные предположения о восстании народов против царей и об учреждении для сего особых товариществ» (Д. 335, лл. 65 об., 66 об.).

Указанные произведения имели выраженную антироссийскую направленность, а факты их хранения и распространения свидетельствовали о проникновении в студенческую среду польских патриотических убеждений сепаратистского характера. При этом конфессиональный и социальный состав этой среды не был однородным: один из упоминавшихся выше студентов был православным, другой происходил из однодворцев, а не из дворян (Д. 335, лл. 65 об., 66 об.). Различался и уровень материального благосостояния: одна половина студентов являлась «казеннокоштной», другая - «своекоштной».

По распоряжению императора Николая I «дело студентов» было передано из Третьего отделения, куда поступили обнаруженные в Киеве «противозаконные рукописи», на рассмотрение министра народного просвещения С.С. Уварова. Последний поручил расследование попечителю Киевского учебного округа Е.Ф. фон Брадке, проводившему его во взаимодействии с генерал-губернатором А.Д. Гурьевым (РГИА. Ф. 735. Оп. 10. Д. 116, л. 68 об.).

Подозреваемые в хранении и распространении рукописей студенты были арестованы и подвергнуты допросам. Часть из них оказалась непричастна к делу, однако шестеро дали признательные показания или были обоснованно уличены другими обвиняемыми. В дальнейшем все изобличенные, за исключе- 
нием студента П. Богдановича, активно сотрудничали со следствием (Д. 116, лл. 69 об.-75).

Вследствие долгого «упорства к сознанию», именно П. Богданович был признан наиболее виновным из всех студентов. По предложению министра народного просвещения С.С. Уварова, лично прибывшего в Киев для контроля над ходом расследования, он был определен на военную службу рядовым в Отдельный Оренбургский корпус (Д. 116, л. 79 об.).

При определении степени вины студента Ю. Буяльского следствие учло не только факты непосредственного участия последнего в распространении «противозаконных рукописей», но и то обстоятельство, что

«и прежде он был поведения не совсем благонадежного и неоднократно подвергался взысканиям, и что в его характере вообще выражается упрямство и фанатизм» (РГИА. Ф. 735. Оп. 10. Д. 116, л. 80).

В отличие от попечителя Киевского учебного округа Е.Ф. фон Брадке, предлагавшего всего лишь исключить Ю. Буяльского из университета и отправить на службу уездным или приходским учителем в Казанский учебный округ, С.С. Уваров счел нужным и этого студента определить в Отдельный Оренбургский корпус (Д. 116, л. 80).

Студента С. Рутковского, вина которого, по заключению следствия, состояла «в прочтении стихов запрещенных и некотором запирательстве», было решено отправить учителем уездного училища в одну из отдаленных губерний Казанского учебного округа (Д. 116, л. 80 об.).

С. Стройновский, ввиду молодости, хорошего поведения, а также того обстоятельства, что он «с полной откровенностью сознался в вине и указал на соучастников», был прощен и оставлен в университете под надзором попечителя (Д. 116, л. 80 об.). Также были освобождены от ответственности давшие признательные показания Р. Станиславский и П. Кунашевский (Д. 116, л. 80 об.). Таким образом, тяжесть наказания обвиняемых по «делу студентов» напрямую зависела от степени сотрудничества со следствием и не всегда совпадала с мерой участия собственно в хранении и распространении «противозаконных» рукописей.

\section{Выводы}

Подводя итоги, отметим следующее. Общественное движение в Юго-Западном крае после подавления восстания 1830 - 1831 гг. развивалось в польском национальном русле. Наиболее распространенными формами проявления оппозиционных настроений были контакты с политическими эмигрантами и ссыльными, ведение антиправительственной пропаганды, хранение и распространение литературы патриотического содержания. Общественное движение не имело четких структурных очертаний: акты проявления 
недовольства политикой властей, как правило, совершались лицами, не объединенными в рамках какой-либо политической организации.

Власть в регионе в рассматриваемый период оказалась перед необходимостью выработки эффективной административной стратегии, направленной на интеграцию края в состав Российской империи. Представители правящих кругов столкнулись с фактическим отсутствием социальной опоры: представители дворянства и духовенства, которые на «коренной» территории империи в подавляющем большинстве были лояльны и служили поддержкой центральной власти, в случае юго-западного фронтира недвусмысленно демонстрировали ярко выраженную оппозиционность, спорадически перераставшую в конкретные «мятежные» действия. Это противоречие между магистральным направлением социальной политики Российского государства и особенностями региона зачастую ставило в тупик представителей администрации и снижало эффективность их действий, особенно на фоне крестьянского движения У.Я. Кармалюка.

Вследствие данного сочетания факторов политика властей по отношению к участникам общественного движения на территории Юго-Западного края отличалась крайней непоследовательностью. Строго говоря, продуманной политической линии в этом вопросе не существовало: как правило, власти отвечали на вызовы «снизу», а эффективность предпринимаемых репрессивных мер во многом снижалась при практическом осуществлении. Полицейский надзор фактически носил формальный характер, позволяя значительной части поднадзорных пользоваться относительной свободой действий. «Исправление службой» в большинстве случаев оставалось декларацией о намерениях со стороны властей, нежели наполнялось реальным содержанием. Многие ссыльные через несколько лет получали высочайшее прощение или существенное смягчение наказания.

Деятельному расследованию политических происшествий на территории края в значительной мере препятствовали ведомственные интересы и нежелание придавать огласку событиям, способным негативно повлиять на служебное положение конкретных чиновников. Как следствие этого, многие участники патриотического движения оставались неподконтрольными и продолжали активную антиправительственную деятельность.

\section{Список литературы}

Bobrowski, T. (1900). Pamietniki [Diaries] (Vol. 1). Wydawnictwo Nakładem funduszu testamentowego. (In Polish).

Głębocki, H. (2006). Kresy Imperium. Szkice i materiały do dziejow polityki Rosji wobec jej peryferii (XVIII - XXI) [Kresy Imperium. Sketches and materials in the history of Russian policy towards its peripheries (18th-21st)]. Wydawnictwo Arcana. (In Polish). 
Limanowski, B. (1957). Historia demokracii polskiej w epoce porozbiorowej [History of Polish democracy in the post-partition era]. Ksiazka i Wiedza. (In Russian).

Remy, J. (2000). Higher education and national identity: Polsky student activism in Russia. 1832 - 1863. Suomalaisen Kirjallisuuden Seura.

Szulc, S. (1868). Pamietnik kapelana [Chaplain's diary]. In Polska w walke. Zbior wspomnien i pamietnikow z dzieow naszego wyjarzmiania [Poland in combat. Collection of memoirs and reminiscences from the history of our liberation] (Vol. 1, pp. 66-143). Księgarnia Luxemburgska. (In Polish).

Варадинов, Н. В. (1862). История Министерства внутренних дел. (Часть 3. Книга 1). Типография Министерства внутренних дел.

Вибе, И. Н. (2008). Католические монастыри в политике российской власти в Западном крае (1831-1832). Известия Российского государственного педагогического университета им. А.И. Герцена, 70-1, 119-121.

Владимирский-Буданов, М. Ф. (1884). История Илператорского университета Св. Владимира (Т. 1). Типография Императорского университета Св. Владимира.

Государственный архив Российской Федерации (ГАРФ). (б. д.). Ф. 109. Оn. 2 a. Д. 283.

Довнар-Запольский, М. В. (1910). Из истории общественных течений в России. Издательство И. И. Самоненко.

Долбилов, М. Д. (2006). От Конституционной хартии к режиму Паскевича. В Западные окраины Российской илперии (сс. 81-122). Новое литературное обозрение.

Дьяков, В. А. (1979). Освободительное движение в России, 1825-1861 г2. Мысль.

Казьмирчук, Г. Д., \& Смирнов, В. Л. (1984). Револющионное двиюение в Киевском университете (1834 - 1861). Киевский государственный университет им. Т. Г. Шевченко.

Кизеветтер, А. А. (1905). Девятнадиатый век в истории России. Донская речь (Н. Парамонов).

Корнилов, А. А. (1915). Русская политика в Польше со времени разделов до начала ХХ века. Исторический очерк. Издательство Огни.

Кулжинский, И. Г. (1865). Воспоминания о Волыни. В Вестник Западной России: Т. 1. Кн. 1. (сс. 1-12). Типография А. К. Киркора.

Манойленко, А. С., \& Манойленко, Ю. Е. (2013). Полицейский надзор в Юго-Западном крае в 1830-х-1850-х гг. Вопросы истории, 10, 120-123.

Манойленко, А. С., \& Манойленко, Ю. Е. (2015). Процесс по делу Ш. Конарского и судьбы польских ссыльных. Вопросы истории, 2, 137-151.

Марахов, Г. И. (1971). Социально-политическая борьба на Украине в 20-40-х годах XIX века. Вища школа.

Марахов, Г. И. (1984). Киевский университет в револючионно-демократическом движении. Киевский государственный университет им. Т. Г. Шевченко.

Мошковский, К. (1909). Рукопись в тюрьме. Русский архив, 4, 483-533.

Оржеховский, И. В. (1982). Самодержавие против револющионной России (1826 - 1880). Мысль. 
Российский государственный исторический архив (РГИА). (б. д.). Ф. 711. Оп. 1. Д. 6, 7, 10; Ф. 733. Оn. 69. Д. 335; Ф. 735. On. 10. Д. 116; Ф. 797. Оn. 4. Д. 14086; Ф. 1151. On. 3. 1843 г. Д. 132; Ф. 1284. Оп. 22. I отд. I cm. Д. 144; Ф. 1286. Оп. 6. Д. 269, 288; Оп. 7. Д. 3.

Селицкий, А. И. (2003). Польская шляхта в социально-правовой системе Российской империи. В Поляки в России: XVII - XX вв. Материалы Международной научной конференции (сс. 105-128). Кубань.

Сидорова, М. В., \& Щербакова, Е. И. (Ред.). (2006). Россия под надзором. Отчёты III отделения, 1827 - 1869: Сборник документов. Российский фонд культуры.

Тихонов, А. К. (2004). Власти и католическое население России в XVIII - XIX веках. Вопросы истории, 3, 140-146.

Удалов, С. В. (2007). Государственная идеология и политика на национальных окраинах Российской империи во второй четверти XIX века (на примере Западных и Северо-Западных губерний). В Проблемы истории российской цивилизащии. Сборник научных статей. Выпуск 3 (сс. 22-40). Научная книга.

Фалькович, С. М. (1997). Концепции славянского единства в польской и русской общественной мысли (Эпоха польских национально-освободительных восстаний). В Славянский вопрос: Вехи истории. Институт славяноведения и балканистики РАН.

Федосов, И. А. (1958). Революционное движение в России во второй четверти XIX века (Революционные организащии и кружки). Соцэкгиз.

Хасимото, Н. (2005). Учебная политика Российской империи в Западных губерниях и «польский вопрос» (конец XVIII в. - Первая половина XIX в.). В Социальная трансформация и межэтнические отношения на Правобережной Украине XIX - начало XX вв. (сс. 132-174). РОССПЭН.

\section{References}

Bobrowski, T. (1900). Pamietniki [Diaries] (Vol. 1). Wydawnictwo Nakładem funduszu testamentowego. (In Polish).

Dolbilov, M. D. (2006). From the Constitutional Charter to the Paskevich regime. In The western fringes of the Russian Empire (pp. 81-122). New Literary Review (In Russian).

Dovnar-Zapolsky, M. V. (1910). From the history of social movements in Russia. I. I. Samonenko Publishing. (In Russian).

Dyakov, V.A. (1979). The Liberation Movement in Russia, 1825-1861. Mysl. (In Russian).

Falkovich, S. M. (1997). Concepts of Slavic unity in Polish and Russian social thought (The era of the Polish national liberation uprisings). In The Slav question: Milestones of history. Institute of Slavonic and Balkan Studies, Russian Academy of Sciences. (In Russian).

Fedosov, I. A. (1958). Revolutionary movement in Russia in the second quarter of the 19th century (Revolutionary organisations and circles). Sotsekgiz. (In Russian).

Głębocki, H. (2006). Kresy Imperium. Szkice i materiały do dziejow polityki Rosji wobec jej peryferii (XVIII - XXI) [Kresy Imperium. Sketches and materials in the history of Russian policy towards its peripheries (18th-21st)]. Wydawnictwo Arcana. (In Polish). 
Hashimoto, N. (2005). Educational policy of the Russian Empire in the Western provinces and the "Polish question" (late 18th century - first half of the 19th century). In Social transformation and inter-ethnic relations in Right-bank Ukraine in the 19th and early 20th centuries. (pp. 132-174). ROSSPEN. (In Russian).

Kazmirchuk, G. D., \& Smirnov, V. L. (1984). The revolutionary movement at the University of Kyiv (1834 - 1861). Kyiv State University named after Taras Shevchenko T. G. Shevchenko. (In Russian).

Kiesewetter, A. A. (1905). The 19th century in Russian history. The Don speech (N. Paramonov). (In Russian).

Kornilov, A. A. (1915). Russian policy in Poland from the time of partitions to the beginning of the 20th century. Historical sketch. Ogni Publisher. (In Russian).

Kulzynski, I. G. (1865). Memories of Volyn. In Bulletin of Western Russia: Vol. 1. Book 1. (pp. 1-12). Printing house of A. K. Kirkor. (In Russian).

Limanowski, B. (1957). Historia demokracii polskiej w epoce porozbiorowej [History of Polish democracy in the post-partition era]. Ksiazka i Wiedza. (In Russian).

Manojlenko, A. S., \& Manojlenko, Y. E. (2013). Police Surveillance in the Southwest Territory in the 1830s-1850s. Historical issues, 10, 120-123. (In Russian).

Manojlenko, A. S., \& Manojlenko, Y. E. (2015). Konarski's trial and the fate of Polish exiles. Historical issues, 2, 137-151. (In Russian).

Marakhov, G. I. (1971). Social and political struggles in Ukraine in the 1820s and 1840s. Vischa shkola. (In Russian).

Marakhov, G. I. (1984). Kyiv University in the Revolutionary Democratic Movement. Kyiv State University named after Taras Shevchenko T. G. Shevchenko. (In Russian).

Moszkowski, K. (1909). Manuscript in jail. Russian Archive, 4, 483-533. (In Russian).

Orzechovsky, I. V. (1982). Autocracy versus revolutionary Russia (1826 - 1880). Mysl. (In Russian).

Remy, J. (2000). Higher education and national identity: Polsky student activism in Russia. 1832 - 1863. Suomalaisen Kirjallisuuden Seura.

Russian State Historical Archive (RSHA). (n. d.). F. 711. In. 1. C. 6, 7, 10; F. 733. In. 69. C. 335; F. 735. In. 10. C. 116; F. 797. In. 4. C. 14086; F. 1151. In. 3. 1843. C. 132; F. 1284. In. 22. I of. I it. C. 144; F. 1286. In. 6. C. 269,$288 ;$ In. 7. C. 3. (In Russian).

Selicki, A. I. (2003). Polish nobility in the socio-legal system of the Russian Empire. In Poles in Russia: XVII-XX centuries. Proceedings of the International Scientific Conference (pp. 105-128). Kuban. (In Russian).

Sidorova, M. V., \& Shcherbakova, E. I. (Eds.). (2006). Russia under Oversight. Reports of Section III, 1827 - 1869: A Collection of Documents. Russian Cultural Foundation. (In Russian).

State Archive of the Russian Federation (SARF). (n. d.). F. 109. In. 2a. C. 283. (In Russian).

Szulc, S. (1868). Pamietnik kapelana [Chaplain's diary]. In Polska w walke. Zbior wspomnien i pamietnikow z dzieow naszego wyjarzmiania [Poland in combat. Collection of memoirs and reminiscences from the history of our liberation] (Vol. 1, pp. 66-143). Księgarnia Luxemburgska. (In Polish). 
Tikhonov, A. K. (2004). The Authorities and the Catholic Population in Russia in the 18th - 19th Centuries. Historical issues, 3, 140-146. (In Russian).

Udalov, S. V. (2007). Government ideology and policy in the national outskirts of the Russian Empire in the second quarter of the nineteenth century (the case of the Western and Northwestern provinces). In Problems of the History of Russian Civilisation. Collection of scientific articles. Issue 3 (pp. 22-40). Scientific book. (In Russian).

Varadinov, N. V. (1862). History of the Ministry of the Interior. (Part 3. Book 1). Printing house of the Ministry of the Interior. (In Russian).

Vladimirsky-Budanov, M. F. (1884). History of St Vladimir's Imperial University (Vol. 1). Print shop of the Imperial University of St Vladimir. (In Russian).

Wiebe, I. N. (2008). Catholic monasteries in Russian policy in the West (1831-1832). Proceedings of the Herzen State Pedagogical University of Russia, 70-1, 119-121. (In Russian). 